\title{
MATERNAL VASCULAR ENDOTHELIAL MARKERS IN PREGNANCIES COMPLICATED BY PRE-ECLAMPSIA
}

\author{
By \\ Atwa, A. Arafa, L. Soliman, A. and Goda, H.
}

From

Medical Biochemistry dept., Cardiology dept., and Obstetric

and Gynaecology dept. Faculty of Medicine, Mansoura University

\begin{abstract}
Aim :

To investigate the level of vascular endothelial growth factor (VEGF) and soluble adhesion molecules; vascular cell adhesion molecule-1 (sVCAM-1) and Intercellular adhesion molecule-1 (sICAM-1) in pregnancies complicated by pre-ec!ampsia.
\end{abstract}

\section{SUBJECTS AND METHODS}

Serum levels of VEGF, sVCAM-1, and sICAM-1 were measured in pregnant women with pre-eclampsia at gestational age between 28-40 weeks and these levels were compared with those of normotensive pregnant women using enzyme-linked immunosorbant assay (ELISA).

\section{RESULTS}

Serum levels of VEGF and 203
SVCAM-1 were significantily higher in pre-eclamptic pregnant women $(p=0.035)$ and $(p=0.04)$ respectively, when compared with normotensive pregnant women, matched for gestational age. While sICAM-1 level was slightly elevated $(p=0.07)$ in preeclamptic pregnancy when compared with normotensive one.

\section{CONCLUSION}

Being potent regulator of vascular permeability and endothelial cell function, VEGF is believed to play an important role in the development of generalized cell dysfunction and in. creased vascular permeability in preeclampsia. Moreover, sVCAM-1 may be considered as possible marker of endothelial cell activation, which may be of pathophysiologic significance in the mechanism of pre-eclampsia development.

MANSOURA MEDICAL JOURNAL 


\section{INTRODUCTON}

Pre-eclampsia represents a heterogeneous collection of clinical disorders that occurs in nearly $7 \%$ of all pregnancies (1). Pre-eciampsia is one of the most important and frequent causes of maternal morbidity and mortality in the developed and developing countries $(1,8)$. There is no sensitive and specific screening test to determine women at risk of developing this pregnancy -induced disorder (1).

Although, the aetiology of preeclampsia is still indefinite, endothelial cell activation or damage is assumed to be of particular pathogenetic significance (8-10). The development of pre-eclampsia begins with loss of vascular responsiveness to vasoactive agents together with development of vasoconstriction, followed by generalized endothelial cell dysfunction, with elevated levels of fibronectin and prothrombotic agents such as von Willebrand factor, and increased vascular permeability (2).

Pre-eclampsia is associated with inadequate trophoblast invasion of the placental bed during placental development (3). This interferes with the normal physiologic adaptation of the spiral arteries, which become occluded by fibrinoid material resulting in impaired uteroplacental blood flow (4). It has been proposed that placenta during pre-eclampsia releases a factor into the maternal circulation, which is responsible for the clevelopment of the maternal syndrome including increased sensitivity to vasopressors, a reduction in intravascular volume, increased coagulation and the development of proteinuria (1).

Vascular endothelial growth factor (VEGF) is a potent angiogenic factor that will induce endothelial proliferation and chemotaxis, and stimulates new blood vessel formation both in vivo and vitro (5). Studying transgenic mice deleted for the VEGF have confirmed the significant role of VEGF in the regulation of angiogenesis where these mice exhibit defective angiogenesis even in VEGF heterozygotes (6). Moreover, VEGF is believed to regulate vascular permeability and plays an important role in the maintenance of vascular integrity $(5,7)$.

Soluble adhesion molecules, such as vascular cell adhesion molecule-1 (VCAM-1) and intracellular cell adhesion molecule-1 (VCAM-1), are known to be increased in the serum of pa- 
tients with pre-eclampsia indicating that these molecules are possible markers of endothelial cell activation (11-13).

\section{SUBJECTS AND METHODS:}

1) Subjects :

Twenty-five pregnant women aged 20-35 years $($ mean $=28$ years) with proved preeclampsia were examined at 25th to 40th week of gestation. Control group comprised 10 pregnant women matched for the same age group and gestational age. They were selected from patients attending the outpatient clinic of Gynaecology \& Obstetric Department, Mansoura University Hospital.

The diagnosis of preeclampsia was based on a blood pressure of at least $140 / 90 \mathrm{mmHg}$, or by an increase of the diastolic blood pressure of greater than $25 \mathrm{mmHg}$ and the development of proteinuria of at least 300 $\mathrm{mg}$ albumin in 24 hours urine collection or the presence of greater than $2+$ of protein on a catheterised specimen.

In patient group, the preeclamptic women gave no prior history of either chronic hypertension or renal disease.
2) Sampling :

Venous blood $(5 \mathrm{ml})$ was collected into plain tubes and allowed to clot at room temperature for $30 \mathrm{~min}$. and non-haemolysed sera were separated by centrifugation at $3000 \mathrm{rpm}$ for 15 min. Sera were then immediately freezed at $-20^{\circ} \mathrm{C}$ till time of analysis for sICAM-1, sVCAM-1 \& VEGF.

3) Assay :

Sera were analysed using Enzyme Linked c-Immunosorbent Assay (ELISA) kit based on Sandwich technique, using specific antibodies for sICAM-1, according to Casansky (14), for sVCAM-1 according to Fortis et al. (15) \& for VEGF according to Hyodo et al. (16).

\section{STATISTICAL ANALYSIS}

Serum levels of SICAM-1, SVCAM1 \& VEGF were calculated and compared using non-parametric methods with Mann-Whitney $U$ test evaluation of differences.

Differences were considered statistically significant when $P<0.05$.

The correlation coefficient ( $r$ ) between various parameters was determined using Statistical Package for Social Science (SPSS) by analysing

MANSOURA MEDICAL JOURNAL 
for Kendall's correlation test.

\section{RESULTS}

Results obtained in the present study demonstrated that there was insignificant increase of serum SICAM-1 in preeclampsia group versus the control group ( $p=0.069)$ as shown in table 1 . While there was statistically significant increase of serum SVCAM1 in preeclampsia group when compared to the control group $(p=0.04)$ (table 2). Also, there was a significant increase in levels of VEGF in preeclampsia group versus the control one $(p=0.035)$ as shown in table 3 .

By application of Kendall's correlation in table 4 the present study showed that in preeclampsia group there was non-significant correlation between:

a) Serum levels of SVCAM-1 and $\operatorname{sICAM}-1(r=+0.167, p>0.05)$ \&

b) Serum levels of VEGF and SICAM$1(r=+0.303, p>0.05)$

While there was a highly significant correlation between serum levels of VEGF and SVCAM-1 $r=+0.89, p<$ 0.001 ).

Table 1. Comparison between serum level of sICAM-1 ( $\mathrm{ng} / \mathrm{ml})$ in preeclampsia group and control group:

\begin{tabular}{|l|l|l|l|l|l|}
\hline \multicolumn{1}{|c|}{ Group } & \multicolumn{1}{|c|}{ Median } & Minimum & Maximum & T & $P$ value \\
\hline Pre-eclampsia & $318 \pm 15.7$ & 225 & 578 & & \\
\hline Control & $294.5 \pm 24.5$ & 219 & 489 & -2.060 & 0.069 \\
\hline
\end{tabular}

Vol. 36, No. 3 \& 4 July., \& Oct, 2005 
Table 2. Comparison between serum level of $\mathrm{sVCAM}-1(\mathrm{ng} / \mathrm{ml})$ in preeclampsia group and control group:

\begin{tabular}{|l|l|l|l|c|l|}
\hline \multicolumn{1}{|c|}{ Group } & \multicolumn{1}{c|}{ Median } & Minimum & Maximum & \multicolumn{1}{c|}{ T } & $P$ value \\
\hline Pre-eclampsia & $874 \pm 57.03$ & 395 & 1552 & & \\
\hline Control & $443 \pm 72.8$ & 368 & 1042 & -2.212 & 0.04 \\
\hline
\end{tabular}

Table 3. Comparison between serum level of VEGF $(\mathrm{pg} / \mathrm{ml})$ in preeclampsia group and control group:

\begin{tabular}{|l|l|l|l|l|l|}
\hline Group & Median & Minimum & Maximum & T & $P$ value \\
\hline Pre-eclampsia & $63 \pm 7.6$ & 81 & 162 & & \\
\hline Control & $35.5 \pm 6.5$ & 12.5 & 26 & -2.487 & 0.035 \\
\hline
\end{tabular}

Table 4. Correlation between serum level of sICAM-1 (ng/ml), sVCAM-1 (ng/ml) \& VEGF $(\mathrm{pg} / \mathrm{ml})$ in preeclampsia group and control group:

\begin{tabular}{|l|l|l|l|}
\hline & & sICAM-1 (ng/ml) & sVCAM-1 (ng/ml) \\
\hline sVCAM-1 (ng/ml) & r & +0.167 & \\
& P & $>0.05$ & \\
\hline VEGF $(\mathrm{pg} / \mathrm{ml})$ & r & +0.303 & 0.890 \\
& P & $>0.05$ & $<0.001$ \\
\hline
\end{tabular}

Where, $r=$ Pearson correlation coefficient

$\mathrm{P}=$ level of significance 
Figure 1: Comparison between serum level of sICAM-1 (ng/ml) in preeclampsia group and control group :

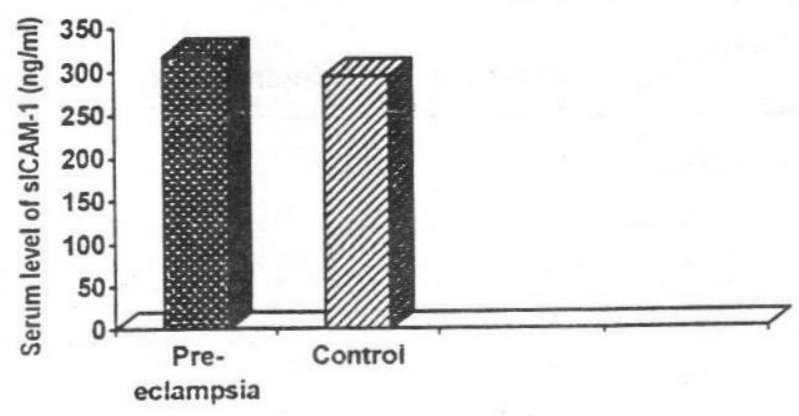

Figure 2: Comparison between serum level of sVCAM-1 $(\mathrm{ng} / \mathrm{ml})$ in preeclampsia group and control group :

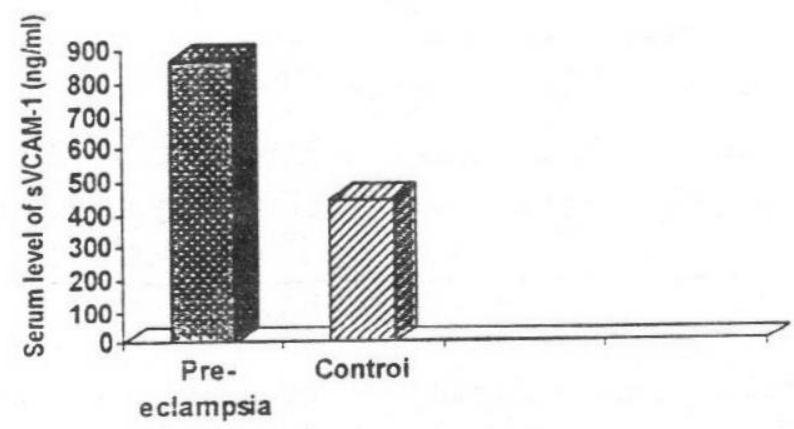

Figure 3: Comparison between serum level of VEGF $(\mathrm{pg} / \mathrm{ml})$ in preeclampsia group and control group :

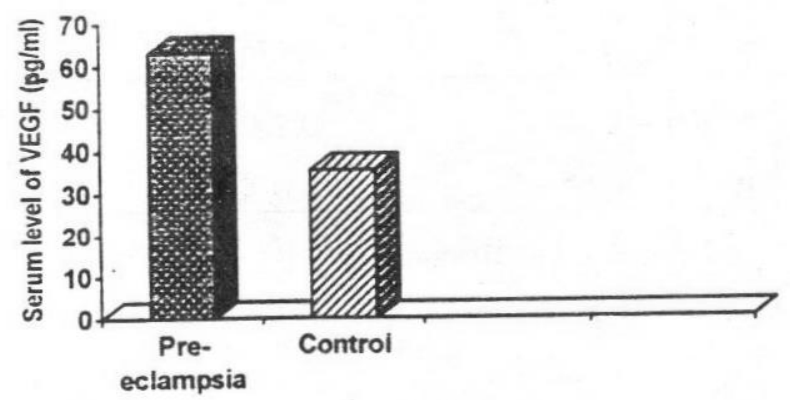

Vol. 3o, No. 3 \& 4 July., \& Oct, 2005 


\section{DISCUSSION}

Endothelial dysfunction is thought to be a central pathogenic feature in preeclampsia on the basis of elevated adhesion molecules. The aim of the present study was to compare the levels of soluble vascular cell adhesion molecule-1 (sVCAM-1), intercellular adhesion molecule-1 (sICAM-1) and vascular endothelial growth factor (VEGF) in sera of normal and preeclamptic pregnancies to elucidate their role in the pathogenesis of preeclampsia. Levels of VEGF were significantly higher in patients with preeclampsia than in those with normal pregnancies, which is in agreement with results of Baker et al. 1995, Sharkey et al. 1996 and McKeeman et al. 2004 (20, 21, 25 respectively). McKeeman et al. 2004 have reported elevated levels of VEGF and its soluble receptor-1 early and throughout gestation with significant increase at 30 weeks' gestation in pre-eclampsia, which can be indicative for definite association between elevated concentration of VEGF and the onset of preeclampsia suggesting a link with disease pathogenesis. This can be explained by the known biological activities of VEGF and its specificity for endothelial cells and vascular permeability control that leads to extra- vasation of plasma proteins. including fibrinogen with reduction of the intravascular volume. This explains some characteristics of pre-eclampsia as proteinuria and increasec vascular permeability (23). Also, Ahmed and Ahmed, 2004 (26) have demonstrated that elevated levels of SVEGF receptor- 1 in preeclampsia is responsible for inhibiting angiogenesis by acting as competitive inhibitor for VEGF antagonizing its effects on the formation of placental vasculature and maternal endothelial cell function in spite of its elevated levels. Recently, SVEGF receptor-1 may be responsible for development of glomerular endotheliosis, the renal lesion seen in preeclampsia (27).

Levels of SVCAM-1 in that study were significantly higher in preeclamptic group than the control one. Our result agrees with those obtained by other investigators $(11,12,28)$. High levels of SVCAM-1 can be an indication of endothelial cell activation as serum concentration of these adhesion molecules may reflect the endothelial membrane-bound ones (11). This is in contrast to the results obtained by (29) where SVCAM-1 serum levels were not associated with the occurrence of pre-eclampsia. 
Our serum levels of SICAM-1 were insignificantly elevated in patients with pre-eclampsia than that in normal pregnant women. This result was in accordance with study of Djurovic et al. i997 (13) who found slightly elevated concentrations in preeclampsia. These results were in contrast with other studies $(18,30,31)$ where there was significant increase in their levels compared to normal pregnancies as a sign of the lymphocyte activation and may be responsible for endothelial destiuction observed in pre-eclampsia.

\section{While Chaiworapongsa et al. 2002} has found no change in SICAM-1 between preeclampsia and normal pregnancy regarding levels of SICAM1 (32), which indicates no endothelial cell activation. Therefore, the pathophysiologic role of this molecule remains unclear that needs further investigation. Differences in the profile of SICAM-1 in various studies may suggest variations in the degrees of endothelial activation between preeclampsia in studied groups.

Study of Heimrath et al. (19) has reported significant increase in sVCAM-1 but not SICAM-1 in patients Vol. 36, No. 3 \& 4 July., \& Oct, 2005 with preeclampsia with increased trophoblastic tissue supporting the hypothesis of vascular endothelial activation during preeclampsia and indicates a relationship between trophoblast in circulation and endothelial activation state.

Also, induction of SVCAM-1 expression observed in preeclampsia may contribute to leucocyte-mediated tissue injury with capture of activated polymorph neutrophils by vascular endothelium augmenting the vascular endothelium damage leading to widespread maternal endothelial dysfunction.

This study also showed statistically significant correlation between serum levels of VEGF and SVCAM-1 but not with sICAM-1 in preeclampsia group.

In summary, endothelial damage and dysfunction are common to all the pathological features of maternal syndrome of pre-eclampsia. The findings of our study show a selective significant elevation of maternal serum SVCAM-1 in preeclampsia. which may indicate leucocyteendothelial attachment and activation. Such increase in soluble circulating 
cell adhesion molecule may reflect increased expression of these molecules on the endothelium and thereby explain the mechanism for leucocyte activation in preeclampsia.

Vascular endothelial growth factor (VEGF) plays a crucial role in physiological vasculogenesis and vascular permeability and has been implicated in the pathogenesis of pre-eclampsia. Our results showed elevated plasma VEGF concentrations in preeclampsia that may be associated with local placental ischemia and endothelial dysfunction, which is a characteristic feature of preeclampsia.

\section{REFERENCES}

1. Roberts JM, Redman CWG. (1993) : Pre-eclampsia: more than pregnancyinduced hypertension. Lancet; 341:1447-51.

2. Brown MA, Zammit VC, Lowe SA. (1989) : Capillary permeability and extra-cellular fluid volumes in pregnancyinduced hypertension. Clin Sci (Lond). Dec;77(6):599604.
3. Pijnenborg R. (1994) : Trophoblast invasion. Reprod Med Rev; 3:53-73.

4. Khong TY, De Wolf F, Robertson WB, Brosens I. (1986) : Inadequate maternal vascular response to placentation in pregnancies complicated by pre-eclampsia and small for gestational age infants. Br J Obstet Gynecol; 93:1049-59

5. Ferrara N, Houck K, Jakeman L, and Leung DW. (1992) : Molecular and biological properties of the vascular endothelial growth factor family of proteins. Endocr. Rev; 13:18-32

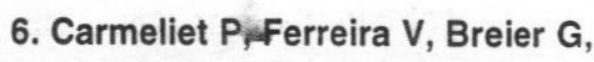
Pollefeyt S, Kieckens L, Gertsenstein M, Fahrig M, Vandenhoeck A, Harpal K, Eberhardt C, Declercq C, Pawling J, Moons L, Collen D, Risau W, Nagy A. (1996) : Abnormal blood vessel development and lethality in embryos lacking a single VEGF allele. Nature. 380:435-439. 
7. Barleon B, Hauser S, Schollmann C, Weindel $K$, Marme D, Yayon A, Weich HA. (1994) : Differential expression of the two VEGF receptors flt and KDR in placenta and vascular endothelial cells. J Cell Biochem.; 54:56-66.

8. Rodgers GM, Taylor RN, Roberts JM. (1988) : Preeclampsia is associated with a serum factor cytotoxic to human endothelial cells. Am J Obstet Gynecol. ; 159:908-14.

9. Roberts JM, Taylor RN, Musci T J, Rodgers GM, Hubel CA, McLaughlin MK. (1989) : Preeclampsia: an endothelial cell disorder. Am J Obstet Gynecol. 161:1200-1204.

10. Roberts JM, Hubel CA, Taylor RN. (1995) : Endothelial dysfunction yes, cytotoxicity no!. Am J Obstet Gynecol.; 173:978-9.

11. Lyall F, Greer IA, Boswell F, Macara LM, Walker JJ, Kingdom JC. (1994) : Tr.e cell adhesion molecule, VCAM1 , is selectively elevated in serum in pre-eclampsia: does this indicate the mechanism of leucocyte activation? Br J Obstet Gynaecol.; 101:485-7.

12. Fickling SA, Whitley GS, Nussey SS. (1995) : The cell adhesion molecule, VCAM-1, is selectively elevated in serum in preeclampsia: does this indicate the mechanism of leucocyte activation? $\mathrm{Br} \mathrm{J} \mathrm{Ob}$ stet Gynaecol. Feb; 102 (2):173-4.

13. Djurovic $S$, Schjetlein R, Wisloff F, Haugen G, Berg K. (1997) : Increased levels of intercellular adhesion molecules and vascular cell adhesion molecules in preeclampsia. Br J Obstet Gynaecol. Apr;104(4):466-70.

14. Casensky (1996) : Adhesion receptors on peripheral blood leukemic cells.; Leukemia 11(3): 408-15.

15. Fortis C, Galli L, Consogno G, ,

Vol. 36, No. 3 \& 4 July., \& Oct, 2005 
Citterio G, Matteucci P, Scaglietti U \& Bucci E. (1995) : Serum levels of soluble cell adhesion molecules (1-CAM-1, V-CAM-1, E-selectin) and cytokines TNF-alpha increase during interleukine-2 Therapy.; Clin Immunol Immuno Pathol 76:142.

16. Hyodo I, Doi T, Endo H, Kotani Y: (1998) : Clinical significance of plasma vascular endothelial growth factor (VEGF) in gastrointestinal cancer. Eur J Cancer.; 34:2041-2045.

17. Heyl W, Handt S, Reister F, Gehlen J, Mittermauer C, Rath W (1999) : The role of soluble adhesion molecules in evaluating endothelial cell activation in preeclampsia. Am J Obstet Gynecol ; 180:68.72.

18. Austgulen R, Lien $E$, Vince G, Redman CW. (1997) : Increased maternal plasma levels of soluble adhesion molecules in pre-eclampsia. Eur J Obstet Gynecol
Reprod Biol; 71:53-8

19. Heimrath J, Krawczenko A, Kozlak J, Dus D. (2004) : Trophoblasts and soluble adhesion molecules in peripheral blood of women with pregnancy-induced hypertension. AJRI; 51:152 .155

20. Sharkey AM, Cooper JC, Balmforth JR, McLaren J, Clark DE, Charnock-Jones DS, Morris NH, Smith SK (1996) : Maternal plasma levels of vascular endothelial growth factor in normotensive pregnancies and in pregnancies complicated by pre-eclampsia. Eur J Clin Invest; 26:1182 -1185.

21.Baker PN, Krasnow J, Roberts JM, Yeo K-T. (1995) : Elevated serum levels of VEGF in patients with preeclampsia. Obstet Gynecol.; 86:815-21.

22. Friedman SA, Taylor RN, Roberts JM. ( 1991) : Pathophysiology of pre-eclampsia. Clin Perinatol; 18:661-82. 
23. Halligan A, Bonnar J, Sheppard $B$, Darling $M$, Walshe J. (1994) : Haemostatic, fibrinolytic and endothelial variables in normal pregnancies and pre-eclampsia. $\mathrm{Br} \mathrm{J} \mathrm{Ob}$ stet Gynaecol. Jun; -101 (6):488-92.

24. Senger DR, Connolly DT, Van de Water L, Feder J, Dvorak HF. (1990) : Purification and $\mathrm{NH} 2$-terminal amirio acid sequence of guinea pig tumor-secreted vascular permeability factor. Cancer Res. Mar 15;50(6):1774-8.

25. McKeeman GC, Ardill JE, Caldwell $\mathrm{CM}$, Hunter $\mathrm{AJ}$, McClure N. (2004) : Soluble vascular endothelial growth factor receptor-1 (sFlt-1) is increased throughout gestation in patients who have preeclampsia develop. Am J Obstet Gynecol. Oct; 191 (4):1240-6.

26. Ahmad S, Ahmed A. (2004): Elevated placental soluble vascular endothelial growth factor receptor- 1 inhibits an- giogenesis in preeclampsia. Circ Res. 2004 Oct 29;95(9):884-91. Epub Oct 07.

27. Eremina V, Quaggin SE. (2004) : The role of VEGF-A in glomerular development and function. Curr Opin Nephrol Hypertens. Jan; 13 (1) : 9-15.

28. Kim SY, Ryu HM, Yang JH, Kim MY, Ahn HK, Lim HJ, Shin JS, Woo HJ, Park SY, Kim YM, Kim JW, Cho EH. (2004) : Maternal serum levels of VCAM-1, ICAM-1 and E-selectin in preeclampsia. $\mathrm{J}$ Korean Med Sci. Oct; 19 (5):688-92.

29. Zeisler H, Livingston JC, Schatten C, Tempfer C, Knofler M, Husslein P. (2001) :

Serum levels of adhesion molecules in women with pregnancy-induced hypertension. Wien Klin Wochenschr. Aug 16;113(15. 16):588-92.

30. Abe E, Matsubara K, Ochi H, Ito M, Oka K, Kameda K. 
(2003) : Elevated levels of adhesion molecules derived from leukocytes and endothelial cells in patients with pregnancy-induced hypertension. Hypertens Pregnancy.; 022(1):31-43.

31. Wilczynski JR, Banasik M, Glowacka E, Tchorzewski H, Malinowski A, Szpakowski M, Wieczorek A, Nowak M, Szpakowski A, Zeman K, Wilczynski J, Biesiada L, Jaczewski B. (2002) : Expression of intercellular adhesion mole- cule-1 (ICAM-1) on the surface of peripheral blood lymphocytes of pregnant women with pregnancy-induced hypertension Ginekol Pol. Jun;73(6):495-500.

32. Chaiworapongsa $T$, Romero R, Yoshimatsu J, Espinoza J, Kim YM, Park K, Kalache K, Edwin S, Bujold E, Gomez R. (2002) : Soluble adhesion molecule profile in normal pregnancy and preeclampsia. J Matern Fetal Neonatal Med. Jul;12(1):1927. 


\section{ولالات وظائف الفشاء المبطن للأوعية الدموية \\ في حالات تسمم الحمل}

$$
\begin{aligned}
& \text { د.أمانى عبد المجيد على عطرة ـلمياء فاروق عرفة }
\end{aligned}
$$

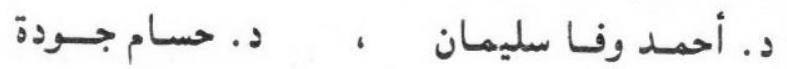

$$
\begin{aligned}
& \text { قسم الكيبيا ، الحيوية الطبية - قسم القلب - قسم النسا ، والتوليد } \\
& \text { كلية الطب - جامعة المنصورة }
\end{aligned}
$$

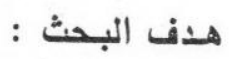

قياس مستوى :لالات وظائف الغشا ، المبطن للأوعبة الدموية فى حالات تسمم الحمل.

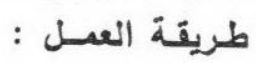

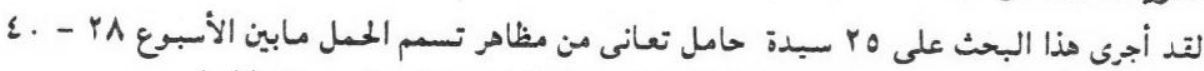

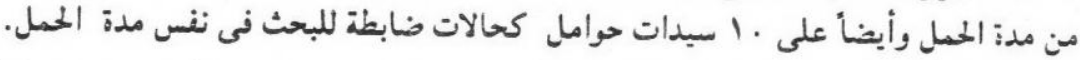

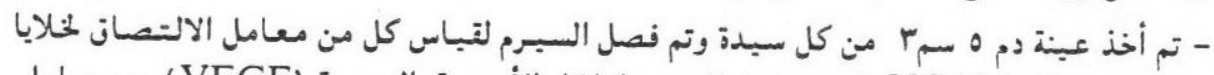

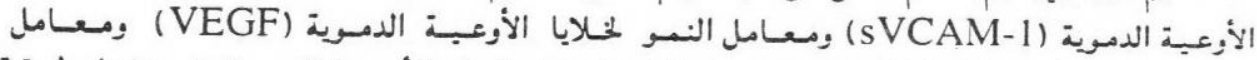

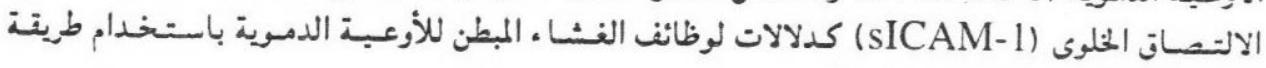

\section{نتيجــة البـــث :}

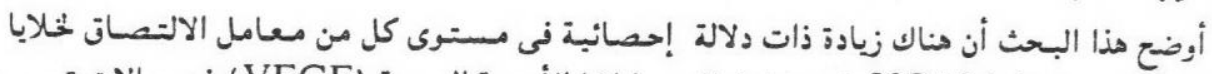

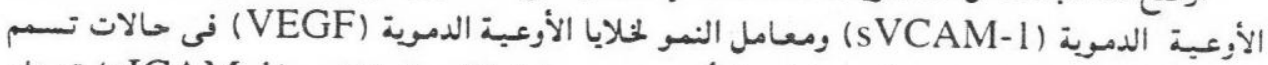

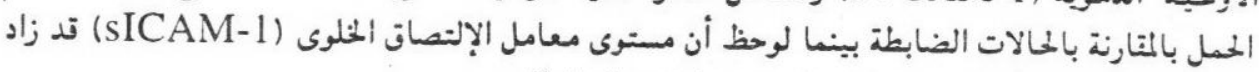

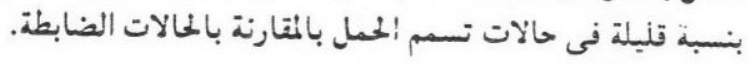

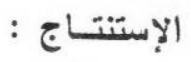

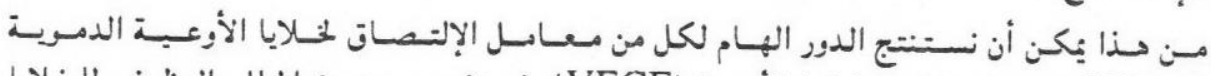

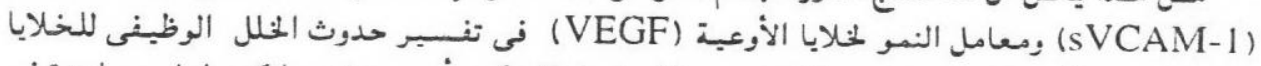

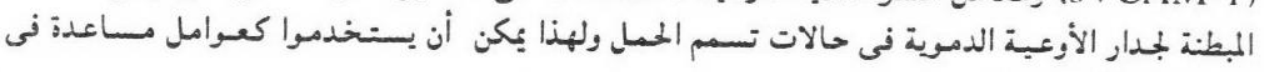
تشخيص هذا المرض.

Vol. 36, No. 3 \& 4 July., \& Oct, 2005 